\title{
Determination of Concentrations of Natural Radionuclides in Soils and Water in Non-cultivated Sites in Seberang Perai, Malaysia
}

\author{
N.A. Alnassar ${ }^{\mathrm{a}, \mathrm{b}}$, M.S. Jaafar ${ }^{\mathrm{b}}$, N.A. Kabir ${ }^{\mathrm{b}}$ \\ ${ }^{a}$ Department of Physics, College of Sciences, Al Imam Mohammad Ibn Saud Islamic University (IMISU), \\ Riyadh, 11623, Saudi Arabia \\ ${ }^{b}$ School of Physics, Universiti Sains Malaysia, 11800 USM, Penang, Malaysia
}

\begin{abstract}
The purpose of this study is to evaluate the level of concentration of radionuclides in Non-cultivated soils and water, which are taken from Seberang Perai in Penang, Malaysia. The concentrations of natural radioactive nuclides; ${ }^{226} \mathrm{Ra},{ }^{232} \mathrm{Th}$, and ${ }^{40} \mathrm{~K}$ were assessed using HPGe detector. The concentrations of ${ }^{226} \mathrm{Ra}$, ${ }^{232} \mathrm{Th}$, and ${ }^{40} \mathrm{~K}$ in soil samples are 4.98 to $160.09,3.43$ to 233.59 and from 56.40 to $819.63 \mathrm{~Bq} \mathrm{~kg}^{-1}$ respectively. The mean concentrations of ${ }^{226} \mathrm{Ra},{ }^{232} \mathrm{Th}$, and ${ }^{40} \mathrm{~K}$ are $36.00,44.21$ and $254.60 \mathrm{~Bq} \mathrm{~kg}{ }^{-1}$ respectively. Similarly, the concentrations of ${ }^{226} \mathrm{Ra},{ }^{232} \mathrm{Th}$, and ${ }^{40} \mathrm{~K}$ in water samples were assessed to be from 0.19 to 2.13 (mean=1.07), 1.15 to 4.32 (mean $=3.08)$ and from 92.37 to 172.43 (mean $=132.43) B q l^{-1}$ respectively. The outcomes using Pearson's correlation shows that the relationship of concentrations of ${ }^{226} \mathrm{Ra},{ }^{232} \mathrm{Th}$ and ${ }^{40} \mathrm{~K}$ amongst soil and water for the researched samples are $R=0.85, R=0.91$ and $R=0.75$ correspondingly with $p<0.05$. Statistical analysis using T-test showed significant distinction between concentrations of ${ }^{226} \mathrm{Ra},{ }^{232} \mathrm{Th}$ and ${ }^{40} \mathrm{~K}$ in soil and water with $t$ values equal to 3.92, 3.12, and 2.57 respectively at $p<0.05$. The results clearly show the values of concentrations of these radionuclides are at the allowable levels with corresponding with dose assessment and radiological indexes.
\end{abstract}

Keywords: Soil, Radioactivity, Water, ${ }^{226} \mathrm{Ra},{ }^{232} \mathrm{Th},{ }^{40} \mathrm{~K}$

\section{Introduction}

Terrestrial radiation originates from the natural radionuclides, which emits gamma rays where individuals are in contact with it inwardly or outwardly. A large portion of these natural radionuclides which are going by uranium $\left({ }^{238} \mathrm{U}\right)$, thorium $\left({ }^{232} \mathrm{Th}\right)$ and potassium $\left({ }^{40} \mathrm{~K}\right)$ are found in the earth's crust. These natural radionuclides are concentrated in rocks and soil in various types and depend on the geology of the areas and geographic conditions, which prompt to expand the effective dose from natural earthbound radiation [1]. The study of terrestrial radiation is noteworthy as well as marker alarm for the man who lives in an area which has a high-concentration in natural radionuclides [2]. Terrestrial radiation in soil may be hazardous people, contingent upon methods of transmission to people, internal and external exposure to gamma rays, consequently, it is extremely imperative to evaluate the concentration of natural radionuclides in soil and water.

There are two courses in which the radionuclides can be transmitted to the human body specifically and in a roundabout way. The immediate course is the point at which the human is exposed to external gamma rays and alpha particles, which are radiated from radionuclides in soil. This external exposure would cause skin blazing and radiation disorder if the concentration of the radionuclides surpassed the allowed universal cutoff point. Likewise, gamma rays and alpha particles are radiated from radon gas $\left({ }^{222} \mathrm{Rn}\right)$, which is the component in uranium-238 chain. Radon gas inhalation is the prime supplier of the external dosage of the total populace [3]. Though, the roundabout way originates from water due to contact with the soil might be subjected to temperament of radionuclides in it, particularly in lakes and rivers as suppliers for drinking water. Along these lines the human body is uncovered through adulterated water by radionuclides to the danger of bio agglomeration, which builds the concentration of these radionuclides in the human body [4]. Previous researches have pointed that the uncloudedness of substantial increment in the concentrations of radionuclides in the soil. The concentration of radionuclides in clay soils of the Nile Delta and Middle Egypt was assessed high [5]. The mean gamma dose rate in soil in Kinta District, Perak, Malaysia is $222 \mathrm{nGy} / \mathrm{h}$, which is twofold of the Malaysia mean and fourfold of the world mean $(59 \mathrm{nGy} / \mathrm{h})$ [6]. The most elevated mean gamma dose rate was assessed to be $375 \mathrm{nGy} / \mathrm{h}$ in Buloh Kasap Mukim in Segamat District, Johor, Malaysia. It indicated six times the mean worldwide dose rate [7]. The most noteworthy evaluated terrestrial gamma-ray concentrations value was $378 \pm 38 \mathrm{nGy} / \mathrm{h}$ in Melaka, Malaysia [8]. The purpose of this study is to assess the level of concentration of radionuclides in non-cultivated soils and water taken from Seberang Perai in Penang. The concentrations of radionuclides were measured by utilizing a hyper-pure germanium detector. An assessment of the biological impacts on people resulting from the natural radioactivity ascending from soils was referred to as the absorbed 
Determination of Concentrations of Natural Radionuclides in Soils and Water in Non-cultivated ..

dose in air, the annual effective dose equivalent, the radium equivalent activity and the external hazard index. This paper introduces the full, concluded analysis of this study.

\subsection{Study Area}

\section{Materials and Methods}

Study about radioactivity of soil has been conducted in Pulau Pinang, however the study is restricted to the part of Penang in the territory. The results of the study were high concentrations of the radionuclides in Penang Island [9]. These reasons drew the attention of the analyst to concentrate on Seberang Perai. It is situated between latitudes $5^{\circ} 33^{\prime} 13.22^{\prime \prime} \mathrm{N}$ and $5^{\circ} 34^{\prime} 24.49^{\prime \prime} \mathrm{N}$ and longitudes $100^{\circ} 20^{\prime} 54.63^{\prime \prime} \mathrm{E}$ and $100^{\circ} 23^{\prime} 56.89^{\prime \prime} \mathrm{E}$ in Penang in Northern Malaysia Peninsula (NMP). It has three regions, which are north, center and south. Table 1 exhibits the geographical areas of chosen samples from every district utilizing the Global Positioning System; Garmin GPS system 60CSx as shown in Fig 1.

Table 1: Geographic site of sampling points

\begin{tabular}{|l|l|l|l|l|}
\hline SC & Sampling Site & Latitude & Longitude & Alev(m) \\
\hline SPS1 & Kampung Besar, Nibong Tebal & $5^{\circ} 10^{\prime} 7.20^{\prime \prime} \mathrm{N}$ & $100^{\circ} 32^{\prime} 0.70^{\prime \prime} \mathrm{E}$ & 25 \\
\hline SPS2 & Kampung Nanas, Nibong Tebal & $5^{\circ} 9^{\prime} 40.20^{\prime \prime} \mathrm{N}$ & $100^{\circ} 31^{\prime} 19.30^{\prime \prime} \mathrm{E}$ & 15 \\
\hline SPS3 & Taman Sungai Kechil, Nibong Tebal & $5^{\circ} 9^{\prime} 57.30^{\prime \prime} \mathrm{N}$ & $100^{\circ} 30^{\prime} 30.20^{\prime \prime} \mathrm{E}$ & 9 \\
\hline SPS4 & Kampung Paya Kemian,Sungai Jawi & $5^{\circ} 11^{\prime} 16.80^{\prime \prime} \mathrm{N}$ & $100^{\circ} 30^{\prime} 36.90^{\prime \prime} \mathrm{E}$ & 23 \\
\hline SPS5 & Kampung Wellesley, Sungai Jawi & $5^{\circ} 12^{\prime} 50.711^{\prime \prime}$ & $100^{\circ} 30^{\prime} 51.78^{\prime \prime} \mathrm{E}$ & 21 \\
\hline SPS6 & Taman Rasa Ria, Sungai Jawi & $5^{\circ} 13^{\prime} 10.90^{\prime \prime} \mathrm{N}$ & $100^{\circ} 29^{\prime} 16.40^{\prime \prime} \mathrm{E}$ & 8 \\
\hline SPS7 & Taman Merpati Indah, Simpang Ampat & $5^{\circ} 15^{\prime} 46.00^{\prime \prime} \mathrm{N}$ & $100^{\circ} 27^{\prime} 7.70^{\prime \prime} \mathrm{E}$ & 9 \\
\hline SPS8 & Villa Tanjung Permai, Simpang Ampat & $5^{\circ} 16^{\prime} 16.00^{\prime \prime} \mathrm{N}$ & $100^{\circ} 26^{\prime} 35.10^{\prime \prime} \mathrm{E}$ & 11 \\
\hline SPT1 & Taman Perwira Indah, Simpang Ampat & $5^{\circ} 17^{\prime} 39.40^{\prime \prime} \mathrm{N}$ & $100^{\circ} 27^{\prime} 58.40^{\prime \prime} \mathrm{E}$ & 5 \\
\hline SPT2 & Kampung Mengkuang, Kubang Semang & $5^{\circ} 23^{\prime} 44.04^{\prime \prime} \mathrm{N}$ & $100^{\circ} 30^{\prime} 40.19^{\prime \prime} \mathrm{E}$ & 46 \\
\hline SPT3 & Taman Perai Utama, Prai & $5^{\circ} 2322.00^{\prime \prime} \mathrm{N}$ & $100^{\circ} 22^{\prime} 30.30^{\prime \prime} \mathrm{E}$ & 6 \\
\hline SPU1 & Permatang Tiga, Penaga & $5^{\circ} 29^{\prime} 50.211^{\prime \prime} \mathrm{N}$ & $100^{\circ} 25^{\prime} 8.84^{\prime \prime} \mathrm{E}$ & 6 \\
\hline SPU2 & Kampung Permatang Haji Hasan, Kepala Batas & $5^{\circ} 29^{\prime} 25.09^{\prime \prime} \mathrm{N}$ & $100^{\circ} 25^{\prime} 41.93^{\prime \prime} \mathrm{E}$ & 7 \\
\hline SPU3 & Kampung Kubang Menerong, Tasek Gelugor & $5^{\circ} 30^{\prime} 59.81^{\prime \prime} \mathrm{N}$ & $100^{\circ} 29^{\prime} 52.52^{\prime \prime} \mathrm{E}$ & 12 \\
\hline SPU4 & Kampung Bakar Kapor, Penaga & $5^{\circ} 32^{\prime} 24.08^{\prime \prime} \mathrm{N}$ & $100^{\circ} 23^{\prime} 25.38^{\prime \prime} \mathrm{E}$ \\
\hline
\end{tabular}

SC: Site code. Alev: Altitude of level of sea.

SPS: Seberang Perai Selatan. SPT: Seberang Perai Tengah. SPU: Seberang Perai Utara

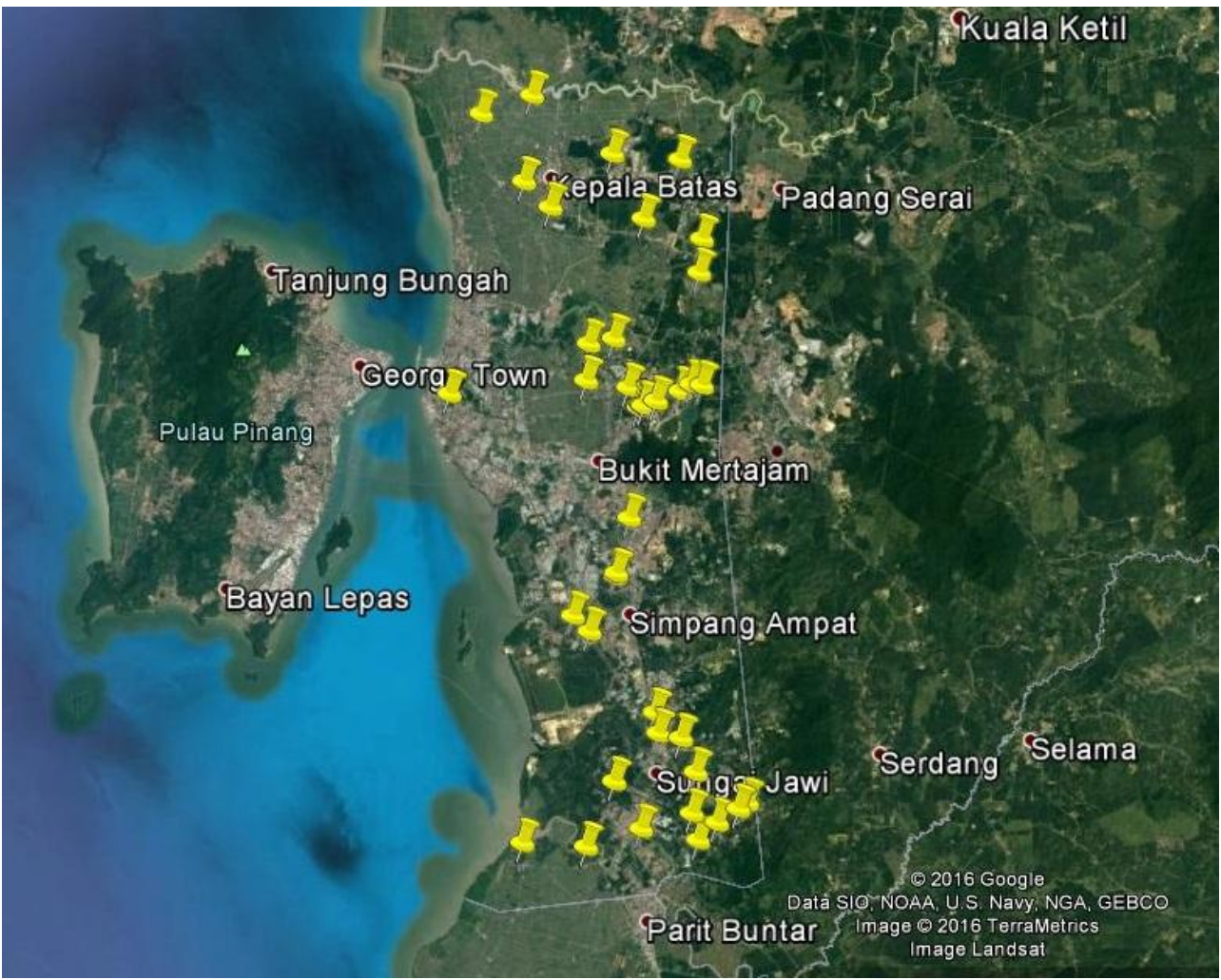

Figure 1: Geographic site of sampling points 


\subsection{Sampling}

The areas were selected on geographical map dividing Seberang Perai into three district. All soil and water samples are chosen depend on the easy reaching by the roads and suitable areas. Soil samples were taken from various regions in Seberang Perai in Penang, without blending of samples to each other. An entire of 20 soil samples were dried at $110^{\circ} \mathrm{C}$ for 24 hours in an oven (Memmert, Germany) for legitimate removal of dampness. Dried samples were ground utilizing vast pestle and mortar of $25.6 \mathrm{~cm}$ diameter (ceramic, England) and after that filtered through a $1 \mathrm{~mm}$ sieve. Every sample was weighed and stocked in a standard Marinella beaker, and after that the standard Marinella beaker was shut utilizing a standard electrical tape. All samples were kept for around 30 days before numbering to accomplish radioactive secular equilibrium for ${ }^{238} \mathrm{U}$ and ${ }^{232} \mathrm{Th}$ with their correspondent progeny [10,11]. All soil samples were set on the HPGe detector for 24h. A sum of (14) water samples $(1000 \mathrm{ml})$ were assembled utilizing plastic jerrican from rivers, streams, lakes, and tap water in these areas as indicated in Table1. Marinella beaker of $1000 \mathrm{ml}$ space was cleaned with dilute hydrochloric acid. At that point they were flushed with distilled water, dried to avert contamination, and loaded with full volumes $(1000 \mathrm{ml})$ of the water sample. The beaker was wrapped and forsaken for four weeks to accomplish common harmony of radionuclides. The water beaker was shaken for $(20 \mathrm{~s})$ to achieve homogenized conveyance of radionuclides into the beaker before beginning the analysis. An empty Marinelli beaker was likewise put for some time (24h) under indistinguishable geometry to resolve the background spectrum. The photopeaks of $\left({ }^{214} \mathrm{~Pb}(351 \mathrm{keV}),{ }^{214} \mathrm{Bi}(609,1120 \mathrm{keV})\right)$ were distinguished to ascertain concentration of ${ }^{226} \mathrm{Ra}$ and the photopeaks of $\left({ }^{212} \mathrm{~Pb}(238 \mathrm{keV}),{ }^{208} \mathrm{Tl}(583 \mathrm{keV}),{ }^{228} \mathrm{Ac}(911 \mathrm{keV})\right)$ were identified to ascertain concentration of ${ }^{232} \mathrm{Th}$, while the photopeak $1460.83 \mathrm{keV}$ was recognized to ascertain concentration of ${ }^{40} \mathrm{~K}$.

\subsection{Gamma-ray spectrometry and calibration}

The HPGe detector (Model No. Pearl M8295P4, Canberra, Inc.) had 115\% relative efficiency and a high-determination of 1.85 for the $1332.5 \mathrm{keV}$ gamma ray line of ${ }^{60} \mathrm{Co}$ source. Calibration sources ${ }^{241} \mathrm{Am},{ }^{137} \mathrm{Cs}$, ${ }^{60} \mathrm{Co}$, and ${ }^{152} \mathrm{Eu}$ (of activities of $331 \mathrm{kBq}, 372 \mathrm{kBq}, 387 \mathrm{kBq}$, and $383 \mathrm{kBq}$, correspondingly) were utilized for a consistent checking time. The absolute detection efficiency of the HPGe detector was resolved utilizing ${ }^{241} \mathrm{Am}$, ${ }^{226} \mathrm{Ra},{ }^{133} \mathrm{Ba},{ }^{137} \mathrm{Cs},{ }^{22} \mathrm{Na},{ }^{60} \mathrm{Co}$, and ${ }^{152} \mathrm{Eu}$ sources at energies from $59.54 \mathrm{keV}$ to $1408.30 \mathrm{keV}$ from the International Atomic Energy Agency, set no. 34 (8 radioactive sources) [10]. The absolute efficiency of the HPGe detector for gamma-ray line was assessed from the formula below:

$$
\varepsilon=\frac{n}{t P_{\gamma}(E) N_{0} e^{-\lambda t_{d}}}
$$

where $\mathrm{n}$ is the net area under the full energy peak, $\mathrm{E}$ is gamma energy (kev), $\mathrm{t}$ is the counting time $(\mathrm{s}), \mathrm{P}_{\gamma}(\mathrm{E})$ is the gamma emission probability at energy $\mathrm{E}, \mathrm{N}_{\mathrm{o}}$; is the activity of the source $(\mathrm{Bq}), \lambda$ is the decay constant of the radionuclides $\left(\mathrm{s}^{-1}\right)$, and $\mathrm{t}_{\mathrm{d}}$ is the decay time(s).

The efficiency calibration curve for the HPGe detector is indicated in Fig. 2. The activity of every specimen was controlled utilizing MAESTRO software with 16,384 channels, licenses data fulfillments, stockpiling, and exhibition of the absorbed spectra. The framework likewise involves the electronic segments that are amplifier and power supply. The HPGe is encircled by a lead protecting $3.5 \mathrm{~cm}$ in thickness, $21 \mathrm{~cm}$ in diameter, and $25 \mathrm{~cm}$ in height to diminish the gamma ray background [12]. The specific activity A (Bq kg-1) is characterized using formula below [13]:

$$
A=\frac{C}{t \varepsilon P_{\gamma} m}
$$

Where $\mathrm{C}=$ Net area under full-energy peak - B.G (count), B.G is the number of counts the background spectrum, $\varepsilon$ is absolute full-energy peak detection efficiency, and $\mathrm{m}$ is the mass of the measured specimen $(\mathrm{kg})$.

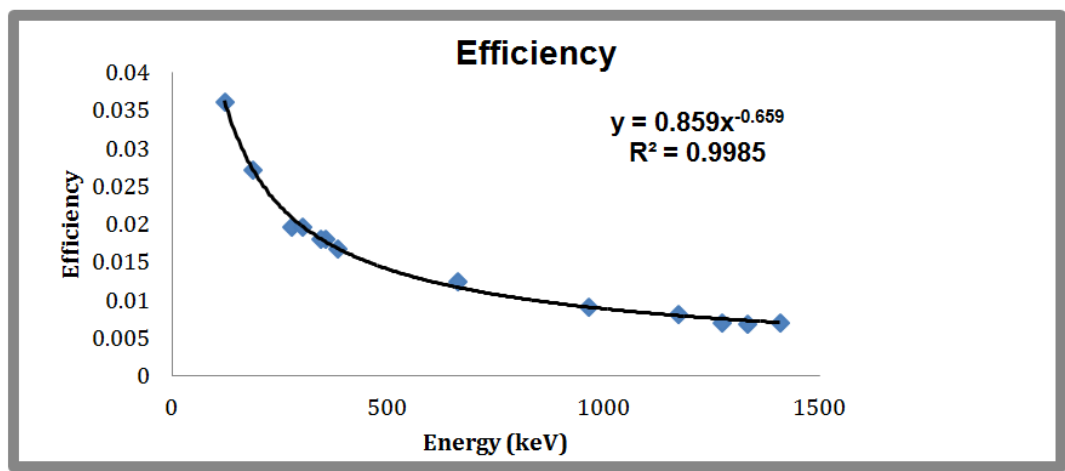

Figure 2: The efficiency of the detector HPGe for every gamma ray line 


\subsection{Dose assessment and radiological hazard indexes}

2.4.1: Absorbed dose rate in air (D)

The absorbed dose rate in outdoor air, D, at $1 \mathrm{~m}$ over the ground were processed utilizing Eq. (3) [1]:

$D\left(\mathrm{nGy} \mathrm{h}^{-1}\right)=0.462 C_{R a}+0.604 C_{T h}+0.0417 C_{K}$

where $\mathrm{C}_{\mathrm{Ra}}, \mathrm{C}_{\mathrm{Th}}$, and $\mathrm{C}_{\mathrm{K}}$ are the activity concentration of ${ }^{226} \mathrm{Ra},{ }^{232} \mathrm{Th}$, and ${ }^{40} \mathrm{~K}$, separately $\left(\mathrm{Bq} \mathrm{kg}^{-1}\right)$.

\subsection{2: Annual effective dose equivalent (AEDE)}

The annual outdoor effective dose equivalent (AEDE) can be assessed by considering the conversion coefficient from absorbed dose rate in air to the effective $\left(0.7 \mathrm{~Sv} \mathrm{~Gy}^{-1}\right)$ and the the outdoor occupancy factor $(0.2)$ [1]. The effective dose equivalent rate can be calculated using Eq. (4):

$\operatorname{AEDE}\left(\mu \mathrm{Svy}^{-1}\right)=D\left(\mathrm{nGyh}^{-1}\right) \times 9800 \mathrm{~h} \times 0.2 \times 0.7\left(\mathrm{SvGy}^{-1}\right) \times 10^{-3}$

\subsection{3: Radium equivalent activity (Raeq)}

The radium equivalent $\left(\mathrm{Ra}_{\mathrm{eq}}\right)$ was utilized as a prominent radiological index to ascertain the activity concentration of ${ }^{226} \mathrm{Ra},{ }^{232} \mathrm{Th}$, and ${ }^{40} \mathrm{~K}$ in the quantified soil samples in light of the fact that the dissemination of natural radionuclides is non-uniform in the soil samples [14]. It can be assessed utilizing Eq. (5):

$R a_{e q}\left(\mathrm{~Bq} \mathrm{~kg}^{-1}\right)=C_{R a}+1.43 C_{T h}+0.077 C_{K}$

where $\mathrm{C}_{\mathrm{Ra}}, \mathrm{C}_{\mathrm{Th}}$, and $\mathrm{C}_{\mathrm{K}}$ are the activity concentration of ${ }^{226} \mathrm{Ra},{ }^{232} \mathrm{Th}$, and ${ }^{40} \mathrm{~K}$ in $\mathrm{Bq} \mathrm{kg}{ }^{-1}$, correspondingly. The most extreme rational value of $\mathrm{Ra}_{\text {eq }}$ must be $370 \mathrm{~Bq} \mathrm{~kg}^{-1}$ to be dependable utilize with an effective dose of $1 \mathrm{mSv}$ for the overall population [1].

\subsubsection{External Hazard Index $\left(\mathrm{H}_{\mathrm{ex}}\right)$}

The external hazard index was utilized to take out the radiation exposure from radionuclides in soils at the level of the cutoff dosage equivalent $1 \mathrm{mSv} \mathrm{y}^{-1}$ utilizing a model suggested by Krieger [15] which is given by Kurnaz in Eq. (6) [16]:

$$
H_{\mathrm{ex}}=\left(\frac{C_{\mathrm{Ra}}}{370}\right)+\left(\frac{C_{\mathrm{Th}}}{259}\right)+\left(\frac{C_{\mathrm{K}}}{4810}\right) \leq 1
$$

The external hazard index must be less or equivalent to unity for a dependable utilization of soils.

\subsection{Soil Radioactivity}

\section{Results and Discussion}

It can be commented that the most astounding mean concentration of activity ${ }^{226} \mathrm{Ra},{ }^{232} \mathrm{Th}$, and ${ }^{40} \mathrm{~K}$ was evaluated to be $102.20 \pm 4.13,119.73 \pm 4.47$ and $459.61 \pm 8.75 \mathrm{~Bq} \mathrm{~kg}^{-1}$, correspondingly, for the soil samples in SPT2, which were obtained from Kampung Mengkuang, Kubang Semang as shown in Fig.3. Similarly, it has been resolved to be the least mean concentration activity of ${ }^{226} \mathrm{Ra},{ }^{232} \mathrm{Th}$, and ${ }^{40} \mathrm{~K}$ to be $5.97 \pm 0.99,6.30 \pm 1.44$ and $56.40 \pm 2.29 \mathrm{~Bq} \mathrm{~kg}^{-1}$ correspondingly, from sample of soil in SPS4 collected from Kampung Paya Kemian, Sungai Jawi (see Table 1). The mean concentrations of ${ }^{226} \mathrm{Ra},{ }^{232} \mathrm{Th}$, and ${ }^{40} \mathrm{~K}$ for all soil samples in this study are seen to be $36.00 \pm 1.60,44.21 \pm 1.78$ and $254.60 \pm 4.26 \mathrm{~Bq} \mathrm{~kg}^{-1}$, correspondingly. From Fig. 3 , obviously ${ }^{40} \mathrm{~K}$ displayed the highest activity concentrations of all quantified radionuclides in the whole of the soil samples. The outcomes of this study have been contrasted with the world mean activity concentrations in soil. As indicated by the UNSCEAR (2000) report, the world mean concentrations are 32,45 and $420 \mathrm{~Bq} \mathrm{~kg}^{-1}$ for ${ }^{226} \mathrm{Ra},{ }^{232} \mathrm{Th}$, and ${ }^{40} \mathrm{~K}$, correspondingly. The common world levels are $16-116 \mathrm{~Bq} \mathrm{~kg}^{-1}$ for ${ }^{226} \mathrm{Ra}, 7-50 \mathrm{~Bq} \mathrm{~kg}^{-1}$ for ${ }^{232} \mathrm{Th}$ and $100-700 \mathrm{~Bq} \mathrm{~kg}{ }^{-1}$ for ${ }^{40} \mathrm{~K}$ concentrations [1]. In relation to the world's standard ranges, the accomplished outcomes show that the scopes of the activity concentrations of ${ }^{226} \mathrm{Ra}$ and ${ }^{232} \mathrm{Th}$ desynchronize from 4.98 to 160.09 and 3.43 to $233.59 \mathrm{~Bq} \mathrm{~kg}^{-1}$, correspondingly. The activity concentrations of ${ }^{226} \mathrm{Ra}$ and ${ }^{232} \mathrm{Th}$ are over the top range of the global values on the grounds that the high concentration value were seen in some soil samples from Kampung Mengkuang, Kubang Semang regions.

The midpoints of the activity concentration of ${ }^{226} \mathrm{Ra}$ and ${ }^{232} \mathrm{Th}$ from samples from Kampung Mengkuang, Kubang Semang areas likewise show relatively higher values than the worldwide mean levels. Although, the general mean activity concentration of ${ }^{226} \mathrm{Ra}$ and ${ }^{232} \mathrm{Th}$ are practically identical to the mean activity worldwide levels. The activity concentration of ${ }^{40} \mathrm{~K}$ in all soil samples differ from 56.40 to $819.63 \mathrm{~Bq}$ $\mathrm{kg}^{-1}$ and bound at the premises of worldwide levels, with a one-sided mean value for the activity concentration of $254.60 \pm 4.26 \mathrm{~Bq} \mathrm{~kg}^{-1}$, which is lower than the worldwide mean value. Likewise, the outcomes displayed in Fig. 3 indicate that soil specimens from Kampung Mengkuang, Kubang Semang areas hold the most astounding activity concentrations of ${ }^{40} \mathrm{~K}$. Accordingly, the higher cconcentrations of ${ }^{226} \mathrm{Ra},{ }^{232} \mathrm{Th}$, and ${ }^{40} \mathrm{~K}$ in some soil samples might be configured in portion by assortment in the geological structure in the study area [17]. 


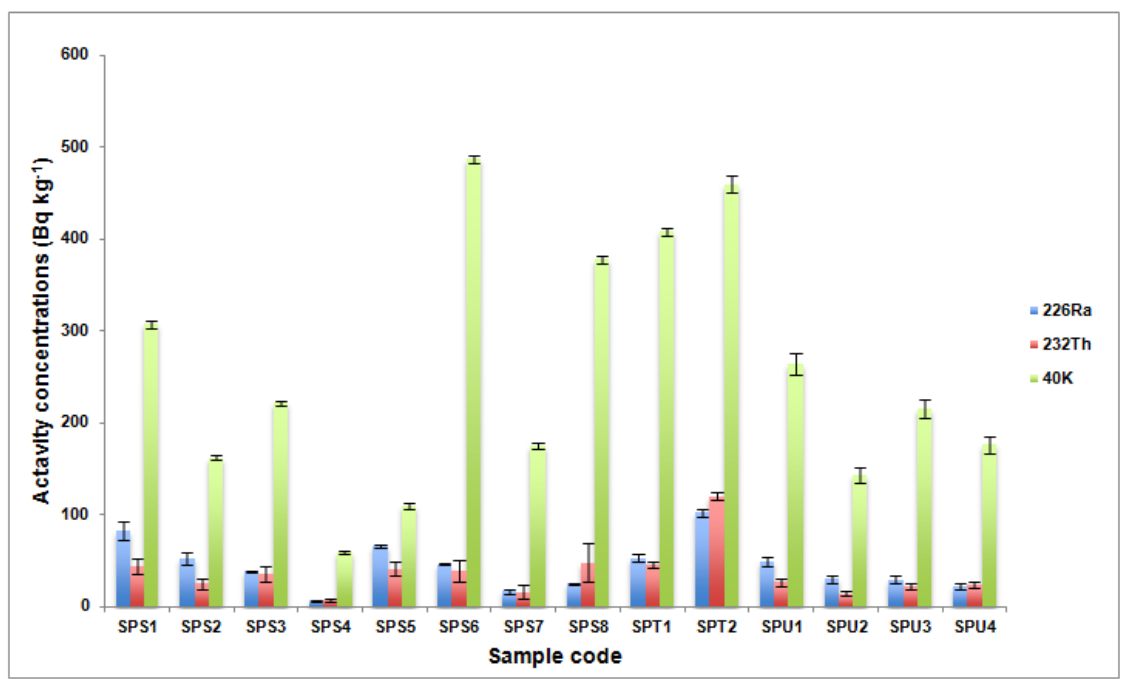

Figure 3: Natural radioactivity in soil samples collected from Seberang Perai

Table 2: The computed absorbed dose rate (D), annual effective dose equivalent (AEDE), radium equivalent activity $\left(\mathrm{Ra}_{\mathrm{eq}}\right)$ and external hazard index $\left(\mathrm{H}_{\mathrm{ex}}\right)$ acquired from all the soil samples evaluated in the current study.

\begin{tabular}{|c|c|c|c|c|}
\hline & $\mathrm{D}\left(\mathrm{nGy} \mathrm{h}^{-1}\right)$ & $\mathrm{AEDE}\left(\mu \mathrm{Sv} \mathrm{y}{ }^{-1}\right)$ & $\mathrm{Ra}_{\mathrm{eq}}\left(\mathrm{Bq} \mathrm{kg}^{-1}\right)$ & $\mathrm{H}_{\mathrm{ex}}$ \\
\hline Min. & $9.08 \pm 1.00$ & $11.14 \pm 1.24$ & $19.51 \pm 2.29$ & $0.05 \pm 0.01$ \\
\hline Max. & $189.02 \pm 21.91$ & $231.81 \pm 26.89$ & $415.52 \pm 50.35$ & $1.12 \pm 0.16$ \\
\hline Average \pm S.D & $53.21 \pm 30.40$ & $65.31 \pm 37.31$ & $115.28 \pm 66.88$ & $0.43 \pm 0.24$ \\
\hline Worldwide & & & & \\
\hline Average & 59 & 70 & Less than 370 & Less than 1 \\
\hline Range & $18-93$ & & & \\
\hline
\end{tabular}

The dose assessment and radiological hazard indexes can be registered from the evaluated activity concentrations of ${ }^{226} \mathrm{Ra},{ }^{232} \mathrm{Th}$, and ${ }^{40} \mathrm{~K}$ in soil samples. The values of these radiological hazard parameters as deduced in this study are arranged in Table 2. From Table 2, the calculated outdoor absorbed dose rates relied on soil radioactivity adjust from $9.08 \pm 1.00$ to $189.02 \pm 21.91 \mathrm{nGy} \mathrm{h}^{-1}$ with a mean value and standard deviation of $53.21 \pm 30.40 \mathrm{nGy} \mathrm{h}^{-1}$. The outcomes calculated from the outdoor air absorbed dose rates fall in the worldwide range aside from the values comparing with sample SPT2 which enrolled higher than the above of top of the world range. The mean value of absorbed dose rate from every one of the samples has been lower than the world mean value. Similarly, the outdoor air annual effective dose equivalent was assessed by considering the conversion coefficients from the outdoor absorbed dose to effective dose and the outdoor occupancy factor. The effective dose for the different sites of soil samples in this study adjusted from 11.14 \pm 1.24 to $231.81 \pm 26.89 \mu \mathrm{Sv} \mathrm{y}^{-1}$, with the mean value and standard deviation of $65.31 \pm 37.31 \mu \mathrm{Sv} \mathrm{\textrm {y } ^ { - 1 }}$, which is least than the world effective dose mean of $70 \mu \mathrm{Sv} \mathrm{y}^{-1}$ [1]. Moreover, the outcomes for the radium equivalent activity $\left(\mathrm{Ra}_{\mathrm{eq}}\right)$ from this study are aggregated in Table 2 . The mean value of radium equivalent activity $\left(\mathrm{Ra}_{\mathrm{eq}}\right)$ for all samples was $115.28 \pm 66.88 \mathrm{~Bq} \mathrm{~kg}^{-1}$ with range differed from $19.51 \pm 2.29$ to $415.52 \pm 50.35 \mathrm{~Bq} \mathrm{~kg}^{-1}$. There is a linear correlation between $\mathrm{Ra}_{\mathrm{eq}}$ values and concentrations of ${ }^{226} \mathrm{Ra}$ for all soil samples, which gives exact assessments of the outcomes as indicated in Fig 4. The $\mathrm{Ra}_{\mathrm{eq}}$ values for the vast majority of the soil samples in this study are lower than the conceded wellbeing cutoff value of $370 \mathrm{~Bq} \mathrm{~kg}^{-1}$ as revealed by the Organization for Economic Cooperation and Development (OECD) [3]. Nevertheless, the top most noteworthy value of $\mathrm{Ra}_{\mathrm{eq}}$ is in the soil specimen of SPT2, which enrolled $415.52 \pm 50.35 \mathrm{~Bq} \mathrm{~kg}^{-1}$ upper value of suggested level. This largest amount tends to the utilizing of soil from Kampung Mengkuang, Kubang Semang ranges as crude materials for the building or agricultural activities sum-up a wellbeing danger of radiation, however, other soils are conducive to exploit, and no radiation hazard emerges from them.

As classified in Table 2, the assessed values of the external hazard index $\left(\mathrm{H}_{\mathrm{ex}}\right)$ for all soil samples broke down range from $0.05 \pm 0.01$ to $1.12 \pm 0.16$ and the mean value was resolved to be $0.43 \pm 0.24$. The results indicated that the $\mathrm{H}_{\mathrm{ex}}$ values for most of the soil specimens are beneath the cutoff of unity, aside from the soil SPT2 with a general mean and standard that the radiation dose is underneath the cutoff point of $1 \mathrm{mSv} \mathrm{y}^{-1}$ endorsed by $[18,19]$. It can be adopted in this study that the general populace living in the under study area are likely not liable to radiological wellbeing hazard considering the findings of the study. 


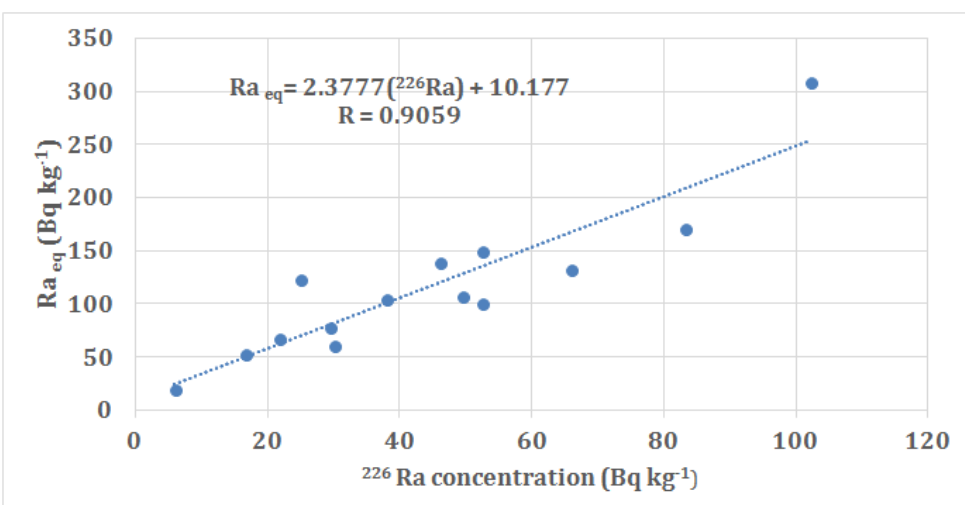

Figure 4: Correlation between ${ }^{226} \mathrm{Ra}$ concentrations and $\mathrm{Ra}_{\mathrm{eq}}$ in soil samples

\subsection{Water radioactivity}

The mean concentration of activity ${ }^{226} \mathrm{Ra},{ }^{232} \mathrm{Th}$, and ${ }^{40} \mathrm{~K}$ were assessed to be $1.07 \pm 0.49,3.08 \pm 0.81$ and $132.43 \pm 23.42 \mathrm{~Bq} \mathrm{l}^{-1}$, correspondingly, for a wide range of water. It can be recognized that the top-most value of the concentration of activity ${ }^{226} \mathrm{Ra}$ was evaluated to be $2.13 \pm 0.25 \mathrm{~Bq}^{-1}$ from lake in SPT2 incorporated into Kampung Mengkuang, Kubang Semang as indicated in Fig.5. On the other hand, it has been found out that the least mean concentrations activity of ${ }^{226} \mathrm{Ra}$ to be $0.19 \pm 0.03 \mathrm{~Bq} \mathrm{l}^{-1}$ from the sample of tap water in SPS1 collected from Kampung Besar, Nibong Tebal (see Table 1). So also, the most astounding value of ${ }^{232} \mathrm{Th}$ was $4.32 \pm 0.87 \mathrm{~Bq} \mathrm{l}^{-1}$ in lake in SPT2 from Kampung Mengkuang, Kubang Semang though the least value was 1.15 $\pm 0.95 \mathrm{~Bq} \mathrm{l}^{-1}$ in the tap water of SPS4 from Kampung Paya Kemian, Sungai Jawi. The water sample of the stream in SPS6 enrolled the top-most concentrations of ${ }^{40} \mathrm{~K}$, which seem to be $172.43 \pm 5.97 \mathrm{~Bq} \mathrm{l}^{-1}$. However, the tap water of SPS4 demonstrated the least value of ${ }^{40} \mathrm{~K}$, which measured to be $92.37 \pm 6.06 \mathrm{~Bq} \mathrm{1}^{-1}$. From Fig. 6 , it is evident that ${ }^{40} \mathrm{~K}$ displayed most noteworthy activity of all quantified radionuclides in most of the water samples included. Table 3 compresses the natural radioactivity levels for all sort of water acquired in some world regions and this study. For instance, the mean value of ${ }^{226} \mathrm{Ra}$ from Yemen is roughly lower than those values [20] and Northern Malaysian Peninsula [10], and lower than that from Nigeria and Sudan [21,22]. The mean values of ${ }^{232} \mathrm{Th}$ concentrations are higher than the values detailed in Yemen and Sudan for lakes water. The ${ }^{40} \mathrm{~K}$ values in this study are higher than the values detailed from different nations except for Northern Malaysian Peninsula, which the outcomes are somewhat comparable.

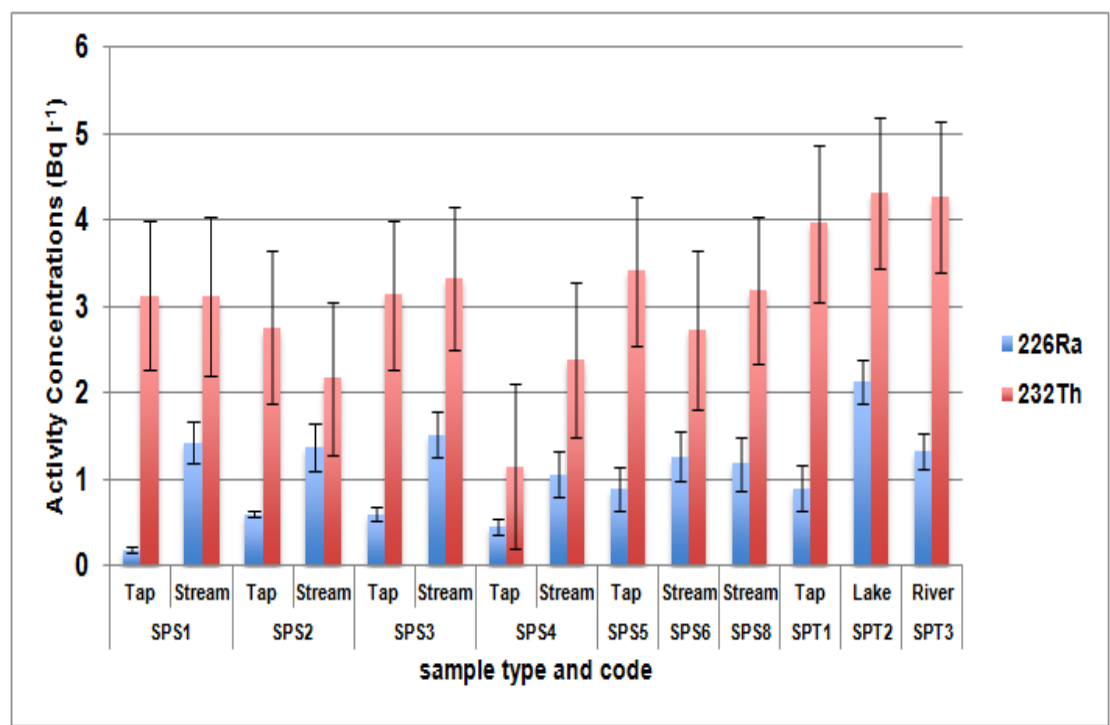

Figure 5: Concentrations of ${ }^{226} \mathrm{Ra}$ and ${ }^{232} \mathrm{Th}$ in water samples collected from Seberang Perai 


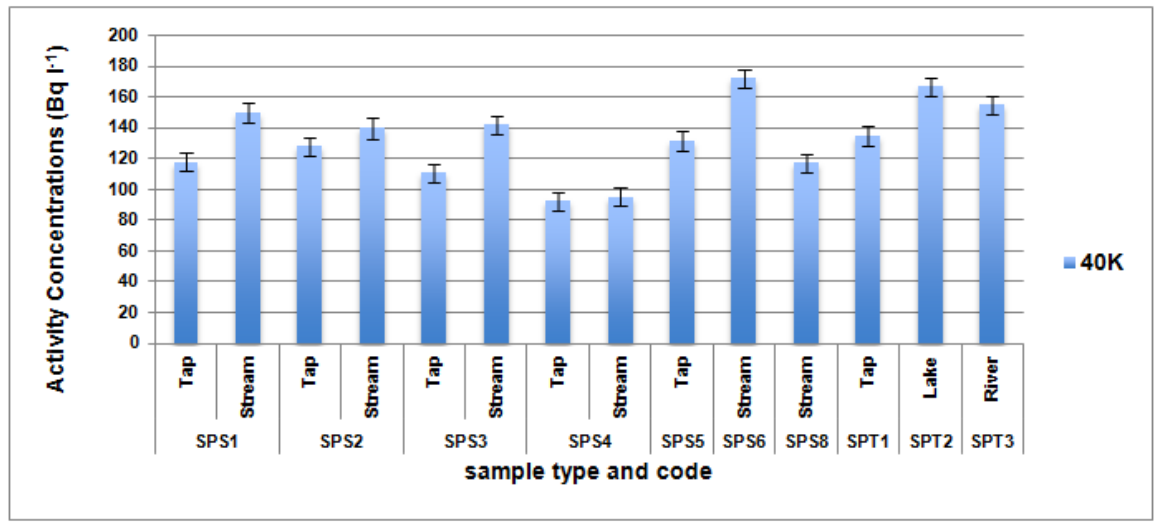

Figure 6: Concentrations of ${ }^{40} \mathrm{~K}$ in water samples collected from Seberang Perai

Table 3: The activity concentrations of natural radionuclides $\left(\mathrm{Bq}^{-1}\right)$ of water samples of Seberang Perai

\begin{tabular}{|c|c|c|c|c|}
\hline Country & Water type & ${ }^{226} \mathrm{Ra}$ & ${ }^{232} \mathrm{Th}$ & ${ }^{40} \mathrm{~K}$ \\
\hline Nigera [21] & Lake & 12 & 12 & 97 \\
\hline \multirow[t]{2}{*}{ Yemen [20] } & Ground & 3.5 & 1.26 & 17 \\
\hline & Spring & 3.48 & 1.00 & 16 \\
\hline \multirow[t]{2}{*}{ Sudan [22] } & Lake & 22.1 & 0.19 & - \\
\hline & Ground & 11.6 & 9.19 & - \\
\hline \multirow[t]{4}{*}{ Malaysia, NMP [10] } & Sea & 3.45 & 3.63 & 190 \\
\hline & Waterfall & 2.00 & 3.80 & 136 \\
\hline & Rain & 2.93 & 3.81 & 148 \\
\hline & River & 2.44 & 3.94 & 118 \\
\hline \multirow[t]{4}{*}{ Malaysia, Seberang Perai $^{\mathrm{P}}$} & Tap & 3.96 & 0.90 & 134.79 \\
\hline & Stream & 3.33 & 1.52 & 172.43 \\
\hline & Lake & 4.32 & 2.13 & 166.99 \\
\hline & River & 4.27 & 1.33 & 154.89 \\
\hline Avg. & & 3.08 & 1.07 & 132.43 \\
\hline
\end{tabular}

\subsection{T-Test and correlations Amongst Soils and Water Radioactivity}

The specific samples are taken to study the variation amongst soil and water radioactivity under T-test with $\alpha=0.05$. It has been ascertained that there is statistically significant variation between concentrations of ${ }^{226} \mathrm{Ra}$ in soil and water which $\mathrm{t}=3.92$ and $\mathrm{p}<0.05$ in samples which soils are in contact with water (stream and lake). Thus, the concentrations of ${ }^{232} \mathrm{Th}$ and ${ }^{40} \mathrm{~K}$ are with $\mathrm{t}=3.12$ and $\mathrm{p}<0.05$, and $\mathrm{t}=2.57$ and $\mathrm{p}<0.05$, correspondingly. Besides, the relationships amongst soils and water radioactivity were tried under linear correlation (Pearson) test with $\alpha=0.05$. It was found that there is the relationship of concentrations of ${ }^{226} \mathrm{Ra}$ amongst soil and water with $\mathrm{R}(12)=0.85$ and $\mathrm{p}<0.05$ as shown in Fig.7. Additionally, the relationship of concentrations of ${ }^{232} \mathrm{Th}$ amongst soil and water has statistically figured to be linear with $\mathrm{R}(12)=0.91$ and $\mathrm{p}<0.05$ as shown in Fig.8. Moreover, the concentrations of ${ }^{40} \mathrm{~K}$ in soils displayed direct connection with concentrations of ${ }^{40} \mathrm{~K}$ in water with $\mathrm{R}(12)=0.75$ and $\mathrm{p}=0.05$ as shown in Fig.9. In this manner, there is a connection between soils radioactivity and water radioactivity when the soils are in contact with water. This connection drives that the expansion of concentrations of natural radionuclides in water is characterized by expanding of these natural radionuclides in soils.

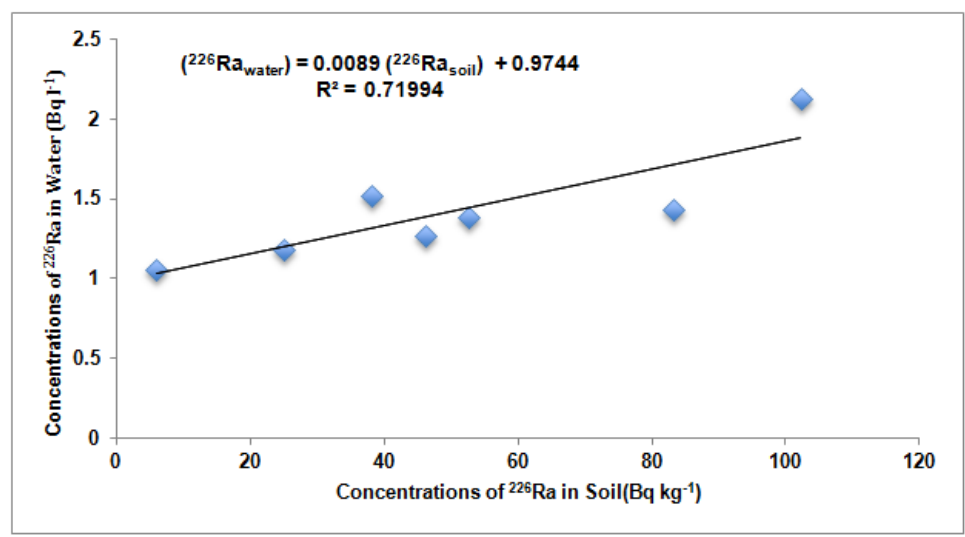

Figure 7: The correlation of concentrations of ${ }^{226} \mathrm{Ra}$ between soil and water in Seberang Perai 


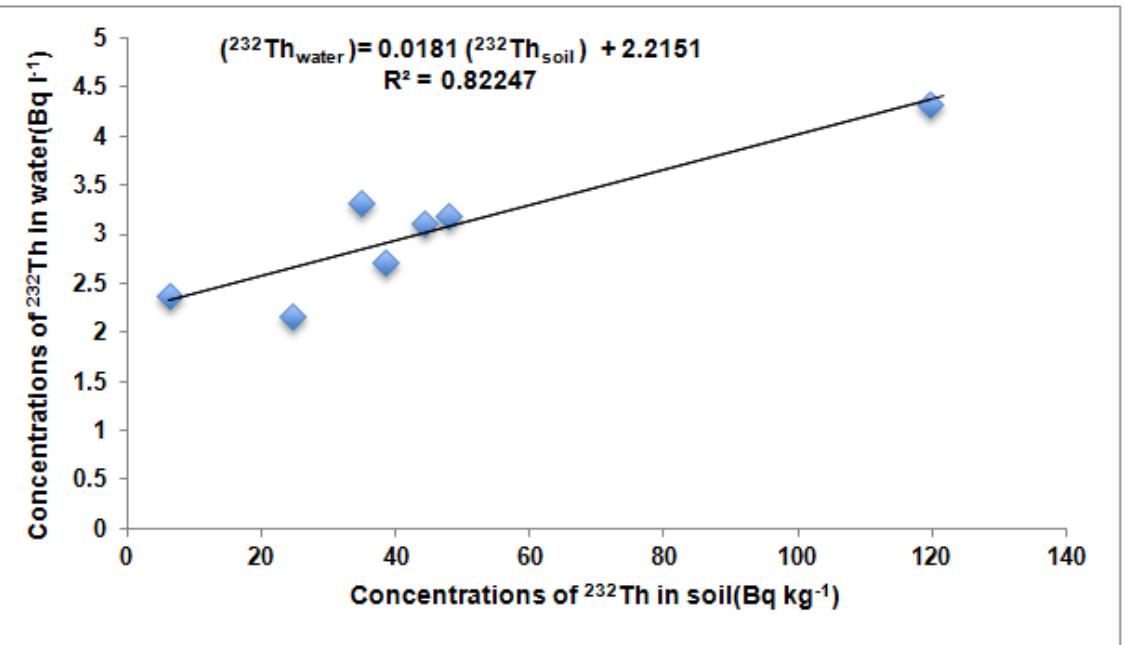

Figure 8: The correlation of concentrations of ${ }^{232}$ Th between soil and water in Seberang Perai

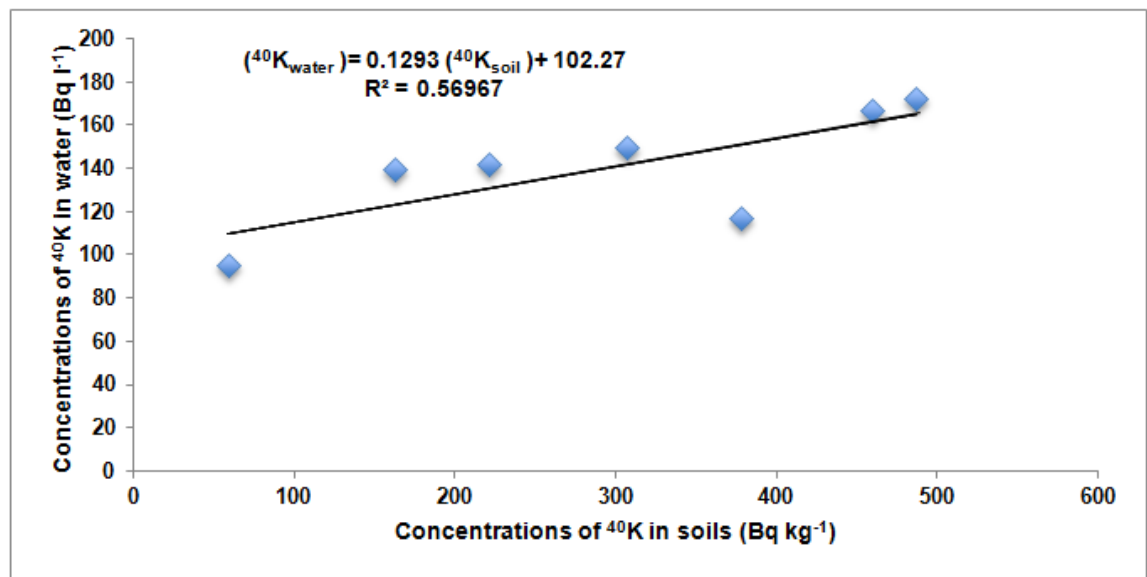

Figure 9: The correlation of concentrations of ${ }^{40} \mathrm{~K}$ between soil and water in Seberang Perai

\section{Conclusion}

In this current investigation, the values confirm that natural radionuclides especially the ${ }^{226} \mathrm{Ra}$ and ${ }^{232} \mathrm{Th}$ and ${ }^{40} \mathrm{~K}$ are constituted in all soils and water samples. The assessed activity concentrations of ${ }^{226} \mathrm{Ra},{ }^{232} \mathrm{Th}$, and ${ }^{40} \mathrm{~K}$ in the entire of the soil samples modified from 4.98 to $160.09,3.43$ to 233.59 and from 56.40 to $819.63 \mathrm{~Bq}$ $\mathrm{kg}^{-1}$ with the mean values of $36.00,44.21$ and $254.60 \mathrm{~Bq} \mathrm{~kg}^{-1}$, correspondingly. The activity concentrations of ${ }^{226} \mathrm{Ra}$ and ${ }^{232} \mathrm{Th}$ are higher than the top scope of the worldwide values in view of the prominent raised levels of radionuclides in some soil samples from Kampung Mengkuang, Kubang Semang areas, though the concentrations of ${ }^{40} \mathrm{~K}$, falls in the world range. The outcomes are influenced by a geological structure variation and therefore may have showed up in the modifications of the concentrations of ${ }^{226} \mathrm{Ra},{ }^{232} \mathrm{Th}$ and ${ }^{40} \mathrm{~K}$ discovered in some soil samples in the territory examined.

For water, the surveyed activity concentrations of ${ }^{226} \mathrm{Ra},{ }^{232} \mathrm{Th}$, and ${ }^{40} \mathrm{~K}$ in the aggregate of the water samples for numerous kinds restored from 0.19 to $2.13,1.15$ to 4.32 and from 92.37 to $172.43 \mathrm{~Bq}^{-1}$ with the mean values of 1.07, 3.08 and $132.43 \mathrm{~Bq} \mathrm{l}^{-1}$, correspondingly. These values of concentrations of water are lower than concentrations of comparable water the world over aside from a few nations. This brought about connections between soil radioactivity and water radioactivity, it was found a connection of concentration of ${ }^{226} \mathrm{Ra},{ }^{232} \mathrm{Th}$ and ${ }^{40} \mathrm{~K}$ amongst soil and water for the examined specimens with relationships $\mathrm{R}=0.85, \mathrm{R}=0.91$ and $\mathrm{R}=0.75$ correspondingly.

The values of the radiation risks and dose assessments from this study are not strikingly high contrasted with the world means, and the prescribed values aside from the soil in Kampung Mengkuang, Kubang Semang, which enrolled high in radium equal activity $\left(\mathrm{Ra}_{\mathrm{eq}}\right)$. Thusly these values are unforeseen to produce more radiological wellbeing hazards to the general population living in the ranges contemplated. Likewise, water can be safe after filtration, and fit for household and industrial purposes. 


\section{Acknowledgements}

The author (Nassar Alnassar) is thankful to Al Imam Mohammad Ibn Saud Islamic University (IMISU) for financial support in the form of scholarship, and Universiti Sains Malaysia for academic support in my Ph.D. research.

\section{References}

[1]. UNSCEAR. (2000). Source and Effects of Ionizing Radiation. United Nations Scientific Committee on the Effects of Atomic Radiation, United Nations, New York.

[2]. Ramli, A. T., Hussein, A. W. M., \& Wood, A. K. (2005). Environmental 238 U and 232 Th concentration measurements in an area of high level natural background radiation at Palong, Johor, Malaysia. Journal of environmental radioactivity, 80(3), $287-304$.

[3]. UNSCEAR. (1988). Sources and Effects of Ionizing Radiation. United Nations Scientific Committee on the Effects of Atomic Radiation, United Nations, New York.

[4]. Malandrino, M., Abollino, O., Buoso, S., Giacomino, A., La Gioia, C., \& Mentasti, E. (2011). Accumulation of heavy metals from contaminated soil to plants and evaluation of soil remediation by vermiculite. Chemosphere, 82(2), 169-178.

[5]. Ibrahiem, N., El Ghani, A. A., Shawky, S., Ashraf, E., \& Farouk, M. (1993). Measurement of radioactivity levels in soil in the Nile Delta and middle Egypt. Health Physics, 64(6), 620-627.

[6]. Lee, S. K., Wagiran, H., Ramli, A. T., Apriantoro, N. H., \& Wood, A. K. (2009). Radiological monitoring: terrestrial natural radionuclides in Kinta District, Perak, Malaysia. Journal of environmental radioactivity, 100(5), 368-374

[7]. Saleh, M. A., Ramli, A. T., Alajerami, Y., \& Aliyu, A. S. (2013). Assessment of environmental 226 Ra, 232 Th and 40 K concentrations in the region of elevated radiation background in Segamat District, Johor, Malaysia. Journal of environmental radioactivity, 124, 130-140.

[8]. Ramli, A. T., Sahrone, S., \& Wagiran, H. (2005). Terrestrial gamma radiation dose study to determine the baseline for environmental radiological health practices in Melaka state, Malaysia. Journal of Radiological Protection, 25(4), 435.

[9]. Almayahi, B., Tajuddin, A., \& Jaafar, M. (2012a). Effect of the natural radioactivity concentrations and 226 Ra/238 U disequilibrium on cancer diseases in Penang, Malaysia. Radiation Physics and Chemistry, 81(10), 1547-1558.

[10]. Almayahi, B., Tajuddin, A., \& Jaafar, M. (2012b). Radiation hazard indices of soil and water samples in Northern Malaysian Peninsula. Applied Radiation and Isotopes, 70(11), 2652-2660.

[11]. Myrick, T., Berven, B., \& Haywood, F. (1983). Determination of Concentrations of Selected Radionuclides in Surface Soil in the US. Health Physics, 45(3), 631-642.

[12]. Tsoulfanidis, N. (1995). Measurement and detection of radiation. Paper presented at the Fuel and Energy Abstracts.

[13]. Dovlete, C., \& Povinec, P. (2004). Quantification of uncertainty in gamma-spectrometric analysis of environmental samples. Quantifying uncertainty in nuclear analytical measurements, 103.

[14]. Beretka, J., \& Mathew, P. (1985). Natural radioactivity of Australian building materials, industrial wastes and by-products. Health Physics, 48(1), 87-95.

[15]. Krieger, R. (1981). Radioactivity of construction materials. Betonwerk Fertigteil Techn, 47, 468.

[16]. Kurnaz, A., Küçükömeroğlu, B., Keser, R., Okumusoglu, N., Korkmaz, F., Karahan, G., \& Çevik, U. (2007). Determination of radioactivity levels and hazards of soil and sediment samples in Firtına Valley (Rize, Turkey). Applied Radiation and Isotopes, $65(11), 1281-1289$

[17]. Al-Hamarneh, I. F., \& Awadallah, M. I. (2009). Soil radioactivity levels and radiation hazard assessment in the highlands of northern Jordan. Radiation Measurements, 44(1), 102-110.

[18]. ICRP. (1991). International Commission on Radiological Protection. ICRP Publication 60, Pergamon Press, Inc, Elmsford, NY.

[19]. ICRP. (2007). The 2007 recommendations of the International Commission on Radiological Protection. ICRP Publication 103 Ann. ICRP 37, 2e4

[20]. El-Mageed, A. I. A., El-Kamel, A. E.-H., Abbady, A. E.-B., Harb, S., \& Saleh, I. I. (2013). Natural radioactivity of ground and hot spring water in some areas in Yemen. Desalination, 321, 28-31.

[21]. Agbalagba, E., \& Onoja, R. (2011). Evaluation of natural radioactivity in soil, sediment and water samples of Niger Delta (Biseni) flood plain lakes, Nigeria. Journal of environmental radioactivity, 102(7), 667-671.

[22]. Osman, A. A., Salih, I., Shaddad, I. A., El Din, S., Siddeeg, M., Eltayeb, H., . . . Yousif, E. (2008). Investigation of natural radioactivity levels in water around Kadugli, Sudan. Applied Radiation and Isotopes, 66(11), 1650-1653. 